\title{
Kansanopistotoimikunnan työ valmistui
}

Vuoden 1979 kansanopistotoimikunta luovutti 19.4.1983 toisen mietintơnsă kulttuuriministeri Arvo Salolle ja kansliapäăllikkઠ Jaakko Nummiselle. Toimikunnan puheenjohtajana toimi professori Kosti Huuhka.

Kansanopistotoimikunta on ollut yksi aikuiskoulutuksen kehittämisen osaprojekti. Toisessa mietinnössään toimikunta tekee kăytănnőllisiă esityksiă kansanopiston toiminnan kehittämiseksi ja esittää kansanopistojen valtionapulain uudistamista. Lähes 250 -sivuisessa mietinnössä on edetty kehittämissuunnittelusta varsinaisiin muutosesityksiin.

Ensimmäisessä mietinnössään (Kom.miet. 1981:11) toimikunta piti kansanopiston ominaispiirteinä:

- sisäoppilaitosmuotoa

- ideologista vapautta

- pedagogista vapautta

- omavastuista tehtävänhakua.

Näiden ominaispiirteiden pohjalta määritellään kansanopisto II mietinnön lakiesityksen 1. pykälässä:

"Kansanopisto on yleissivistävää aikuiskoulutusta antava sisäoppilaitos.

Kansanopisto voi antaa myös ammattikoulutusta siten kuin asetuksessa säädetään."'

Mietinnössään toimikunta tekee ehdotuksia kansanopiston kehittämiseksi moniarvoisena, mutta samalla rakenteellisesti ja toiminnallisesti yhtenäisenä oppilaitoksena. Tämän periaatteen mukaan tulisivat kaikki kansanopistot toimimaan samojen valtionapuehtojen puitteissa ja samalla poistettaisiin ero varsinaisen kansanopiston ja kansankorkeakoulun văliltă.

Toimikunta ei lähtenyt rakentamaan keskenăăn vaihtoehtoisia yhteiskuntakehityksen skenaarioita, joita sitten olisi vertailtu keskenăăn, vaan se edellytti kansanopistoilla itsellăăn olevan kyvyn yhteiskunnallisten muutos- ten seuraamiseen ja siită johtuvien uusien koulutustehtävien suorittamiseen. Toimikunta on tăltă pohjalta pyrkinyt kehittămăăn valtionapuehtoja entistă văljemmiksi, jotta opistot voisivat uudistua itsesăăteisesti ja jărjestăă toimintansa nykyistă vapaammin.

\section{Toimikunnan keskeiset ehdotukset}

Toimikunta esittää yhtenäisestä kansanopistosta käytettäväksi yksinomaan kansanopistonimeä.

Nykyinen, vähintään 24 viikkoa kestävä perusoppijakso esitetään lyhennettäväksi 12-viikkoiseksi ja kurssien minimipituus viidestä päivästä kolmeen päivään. Alle neljä viikkoa kestävien kurssien opiskelijoiden matkakustannukset esitetään valtionavun piiriin kuten on opintokeskusten kurssien kohdalla. Nämä esitykset merkinnevät kansanopiston kurssitoiminnan laajentumista. Nykyisellään kurssien opiskelijaviikkojen mäără on noin $18 \%$ opiskelijaviikkojen kokonaismäărăstă.

Valtionavun myöntämisen perusteena on nykyisin vähintään 25 opiskelijan osallistuminen vähintään 24-viikkoiselle perusoppijaksolle. Tämä esitetään korvattavaksi toiminnan määrän ja opiston kapasiteetin (=opiskelijapaikkamäärä) suhteella. Toimikunta esittää, että opiston tilojen tulisi olla kapasiteetin mukaisessa käytössä vähintään 26 viikkoa työvuodessa. Jos käyttötehokkuus jää alle 26 viikon vähennetään valtionapua eräiltä osin.

Toimikunta on myös esittänyt viikottaisen opiskelijakohtaisen oppituntimäärän alentamista 30:sta 25:een, sekä nykyisin käytössä olevan opetustuntimäärän ja opiskelijaviikkojen suhteen sisällyttämistä lakiin. Tällä suhdeluvulla säädellään opetusryhmien keskimääräistä kokoa, sillä ehdotukseen ei sisälly määräyksiä opetusryhmän vähimmäiskoosta. 
Valtionapuprosentiksi esitetään 80 ja uudeksi valtionapujärjestelmäksi yhdistettyä menoja tuloperusteista mallia, jossa menoperusteisen (palkat ja vuokrat) valtionavun osuus olisi noin $84 \%$ ja opiskelijaviikkomäärään perustuvan suoriteperusteisen valtionavun osuus noin $16 \%$. Menoperusteinen valtionavun osa antaisi opistojen taloudelle vankan pohjan. Suoriteperusteinen osa tehostaisi toimintaa. Valtionapu pysyisi toimikunnan ehdotusten pohjalta suunnilleen nykyisen suuruisena. Henkilökunnan lisäyksestä ja kurssilaisten matkakustannusten korvaamisesta aiheutuisi noin $2 \%$ valtionavun kasvu.

Mietinnössä on lisäksi tarkasteltu kansan- opiston henkilökuntaa, opiskelijoita, pedagogisia kysymyksiä sekä tiloja ja rakentamistarvetta.

Toimikunnan toimeksiannosta suoritettiin selvitys kansanopiston opiskelijoiden koulutus- ja uravalinnoista, sekä toteutettiin selvitykseen liittyvä seurantatutkimus. Lisäksi toimikunnan esityksestä on aloitettu tutkimus kansanopistosta sisäoppilaitoksena, jonka odotetaan antavan uutta tietoa siitä ja sen pedagogisesta merkityksestä.

Mietintö ilmestyy komiteamiet:ntöjen sarjassa (1983:37) juhannuksen tienoilla. 